\title{
Poikimista edeltävän ruokinnan vaikutus lypsylehmien rasvakudoksen energia-aineenvaihduntaan liittyvien geenien toimintaan
}

\author{
Katariina Vara ${ }^{1}$, Seija Jaakkola ${ }^{1}$, Siru Salin ${ }^{1}$, Juhani Taponen ${ }^{2}$, Aila Vanhatalo ${ }^{1}$, Tuomo Kokkonen ${ }^{1}$ ja \\ Kari Elo \\ ${ }^{1}$ Maataloustieteiden laitos, PL 27, 00014 Helsingin yliopisto, ${ }^{2}$ Helsingin yliopisto, Kliinisen tuotan- \\ toeläinlääketieteen osasto, 04920 Saarentaus, sähköpostiosoitteet etunimi.sukunimi@helsinki.fi
}

Aiemmissa tutkimuksissa poikimista edeltävän ruokinnan korkea energian saanti on yhdistetty lisääntyneeseen metaboliseen stressiin poikimisen jälkeen. Lehmillä stressiä ilmentäviä tekijöitä ovat esimerkiksi lisääntynyt kudosten insuliiniresistenssi, lisääntynyt rasvan kertyminen ja mobilisaatio. Tutkimuksen hypoteesina on että ummessaoloajan energian saanti vaikuttaa insuliiniresistenssiin, lipogeneesiin ja lipolyysiin liittyvien geenien toimintaan. Tutkimukseen valittiin 9 geeniä, jotka liittyvät em. ilmiöihin ja joiden toimintaa tutkittiin ihonalaisesta rasvakudoksesta otetuilla näytteillä. Geenitoiminnan eroja arvioitiin kahden energian saanniltaan eri tavoin ruokitun lehmäryhmän välillä sekä eri näytteenottoaikojen välillä.

Ummessaolokaudella kahta kahdeksan ayrshire-lehmän ryhmää ruokittiin joko rajoitetusti tai vapaasti. Lehmät saivat pelkästään säilörehua 6-4 viikkoa ennen odotettua poikimista. Tänä aikana rajoitetusti ruokitut lehmät saivat $100 \%$ (ryhmän keskiarvo $95 \mathrm{MJ} / \mathrm{d}$ ) ja vapaasti ruokitut käytännössä $150 \%$ (keskiarvo $144 \mathrm{MJ} / \mathrm{d}$ ) laskennallisesta energiantarpeestaan. Tunnutusruokinnan alkaessa kolme viikkoa ennen odotettua poikimista, vapaasti ruokitun ryhmän energian saantia alettiin rajoittaa siten, että laskennallinen energian saanti aleni vertailuryhmän tasolle ennustettuun poikimapäivään mennessä. Molempien ryhmien ruokintaan sisältyi kolmen viimeisen tiineysviikon aikana väkirehua $30 \%$ rehuannoksen energiasisällöstä. Tunnutusruokinnan aikana ryhmien energian saannin keskiarvot olivat $107 \mathrm{MJ} / \mathrm{d}$ rajoitetusti ja $135 \mathrm{MJ} / \mathrm{d}$ vapaasti ruokitulla ryhmällä. Poikimisen jälkeen molempien ryhmien ruokinta oli samanlainen. Molemmista ryhmistä jouduttiin poistamaan yksi lehmä ensimmäisellä viikolla poikimisen jälkeen.

Ihonalaisesta rasvakudoksesta kerättiin biopsioimalla näytteet kahdeksan päivää ennen sekä yksi ja yhdeksän päivää jälkeen poikimisen. Kudosnäytteistä eristettiin kokonais-RNA, jonka laatu analysoitiin sekä elektroforeettisesti että spektrofotometrisesti. Geenitoiminnan tutkimus tehtiin kvantitatiivisellä PCR:1lä. Tutkitut geenit olivat: adiponektiini (ADIPOQ), interleukiini-6 (IL-O), insuliinireseptorisubstraatti (IRS), leptiini (LEP), fosfoenolipyruvaattikarboksikinaasi 1 (PCK1), peroksisomiproliferaattoreilla aktivoituva reseptori gamma $(P P A R \gamma)$, retinolia sitova proteiini $4(R B P 4)$, resistiini $(R E S)$ ja tuumorinekroositekijä-alfa $(T N F \alpha)$.

Koko aineistossa lehmien rasvakudoksen geenitoiminnasta löytyi eroja kolmen näytteenottoajankohdan välillä seuraavilla geeneillä: $A D I P O Q, L E P, R E S, P P A R \gamma, R B P 4$ ja $P C K 1(\mathrm{P}<0,05)$. Selkein ajallinen geenitoiminnan ero havaittiin leptiinigeenissä $(\mathrm{P}=0,001)$, jonka toiminta oli poikimisen jälkeen $46 \%$ siitä mitä se oli 8 päivää ennen poikimista. Rajoitetusti ja vapaasti ruokittujen ryhmien välillä oli geenitoiminnassa eroja ennen poikimista. Tilastollisesti merkitsevin ero oli insuliinireseptorisubstraattigeenin toiminnassa $(\mathrm{P}=0,021)$. Lisäksi suuntaa antavasti $(\mathrm{P}<0,10)$ eroja oli adiponektiinija resistiinigeenien toiminnassa.

Poikimisen jälkeen (1 ja 9 päivää) kandidaattigeenien toiminnassa tapahtuneita muutoksia analysoitiin yksilöittäin insuliiniresistenssin näkökulmasta. Tällöin geenitoiminnan perusteella kolmella vapaasti ruokitulla lehmällä on suuntaa antavasti $(\mathrm{P}<0,10)$ ja yhdellä rajoitetusti ruokitulla lehmällä on tilastollisesti merkitsevästi $(\mathrm{P}<0,05)$ insuliiniresistenssin piirteitä.

Asiasanat: energiavaje, metabolinen stressi, ihonalainen rasvakudos, lipolyysi, lipogeneesi, geenitoiminta, lähetti-RNA 


\section{Johdanto}

Aiemmissa tutkimuksissa erityisesti poikimista edeltävän ruokinnan korkea energian saanti on yhdistetty lisääntyneeseen metaboliseen stressiin poikimisen jälkeen (Kokkonen ym. 2005, Nielsen ym. 2010). Tämä tutkimus on osa laajempaa tutkimushanketta, joka tutkii poikimista edeltävän ruokinnan vaikutusta metaboliseen stressiin ja sen taustalla oleviin fysiologisiin mekanismeihin. Geenitoiminnan tutkimus on osa metabolisen stressin fysiologisten mekanismien tutkimusta. Tutkimushankkeessa analysoidaan geenitoiminnan muutoksia maksassa ja ihonalaisessa rasvakudoksessa, jotka ovat metabolisen stressin kannalta tärkeitä kudoksia.

Lypsylehmän rasvakudoksille sopeutuminen maidontuotannon käynnistymiseen tarkoittaa rasvojen varastoinnin (lipogeneesin) vähenemistä ja jo varastoitujen rasvojen mobilisointia (lipolyysiä). Rasvan mobilisoinnin seurauksena vapaiden rasvahappojen pitoisuus plasmassa lisääntyy. Vapaat rasvahapot hapettuvat joko täydellisesti tai epätäydellisesti ketoaineiksi tai ne varastoidaan triglyserideinä maksaan tai ne käytetään maitorasvan synteesissä. Veren vapaiden rasvahappojen pitoisuuden kohoaminen ja rasvan kertyminen kudoksiin inhiboivat insuliinin stimuloimaa glukoosin käyttöä soluissa ja voimistavat edelleen perifeeristen kudosten insuliiniresistenssiä (Pires ym. 2007, Bossaert ym. 2008, Salin ym. 2010). Lisäksi kroonisena vaikutuksena korkea veren vapaiden rasvahappojen pitoisuus voi heikentää myös glukoosin stimuloimaa insuliinin eritystä haimasta (Bossaert ym. 2008).

Rasvakudoksessa tapahtuvista geenitoiminnan muutoksista lopputiineyden ja alkulaktaation aikana on tehty useita tutkimuksia (Sumner \& McNamara 2007, Lemor ym. 2009, Sadri ym. 2010, 2011, Sumner-Thomson ym. 2011). Geenitoiminnan muutokset tunnetaan varsin hyvin vaikka useimmat tutkimuksista keskittyvät muutamien valikoitujen geenien tutkimiseen. Yksittäisten geenien tutkimuksesta poikkeuksena Sumner-Thomson ym. (2011) ovat analysoineet lypsylehmien rasvakudoksen geenitoimintaa genomitasolla. He tutkivat 11 holstein-rotuisella eläimellä geenien toimintaa 30 päivää ennen ja 14 päivää jälkeen poikimisen. Mainitulla ajanjaksolla 433 geenin toiminta lisääntyi vähintään kaksinkertaiseksi ja 30 geenin toiminta väheni vähintään 75 \% (Sumner-Thomson ym. 2011). Esimerkiksi rasvahappojen kuljetukseen liittyvien geenien (FABP4 ja FABP5) ja lipolyysiä kontrolloivien geenien ( $A D R B 2$ ja $L I P E)$ toiminta voimistui ja lipogeneesiin vaikuttavien entsyymigeenien (SREBP, TSHSP, LPL ja ACACA) toiminta väheni (Sumner-Thomson ym. 2011).

Rasvakudos tunnetaan paitsi energiavarastona, myös endokriinisenä elimenä, jolla on immuunivasteeseen ja aineenvaihdunnan säätelyyn liittyviä tehtäviä (Lemor ym. 2009, Mukesh ym. 2010, Sadri ym. 2010). Merkittävä osa rasvakudoksen molekyylitason toiminnan ymmärryksestä perustuu ihmisellä ja laboratorioeläimillä tehtyihin tutkimuksiin. Tässä tutkimuksessa tutkittaviksi geeneiksi on valikoitu adiposytokiinien geenejä sekä insuliinin signalointiin ja lipogeneesiin vaikuttavia geenejä. Kaikkien geenien tiedetään vaikuttavan joko suoraan tai välillisesti insuliiniresistenssiin joko lypsykarjalla tai laboratorioeläimillä tehtyjen tutkimusten perusteella.

Adiposytokiinit, $A D I P O Q, I L-6, L E P, R B P 4, R E S$ ja $T N F \alpha$, erittyvät rasvakudoksesta ja ne säätelevät aineenvaihduntaa auto- para- tai endokriinisesti (Pittas ym. 2004, Yang ym. 2005). Osa adiposytokiineistä säätelee insuliiniresistenssiä ja glukoosin kuljetusta (Pittas ym. 2004, Lemor ym. 2009, Sadri ym. 2010, Yang ym. 2005). Insuliinireseptorisubstraatti (IRS) on yksi keskeisistä insuliinin signalointiin vaikuttavista geeneistä (Sadri ym. 2010). Fosfoenolipyruvaattikarboksikinaasi 1 (PCKI) osallistuu lipogeneesiin ja sillä on vaikutusta triglyseridien kuljetukseen maksan ja rasvakudoksen välillä (Millward ym. 2010). Peroksisomiproliferaattoreilla aktivoituva reseptori gamma $(P P A R \gamma)$ on transkriptiotekijä, joka säätelee useita insuliiniresistenssiin vaikuttavia geenejä (Millward ym. 2010).

Tässä tutkimuksessa edellä mainittujen geenien toimintaa analysoimalla arvioidaan ummessaoloajan energian saannin vaikutusta metaboliseen stressiin. Lisäksi tutkitaan poikimisen yhteydessä tapahtuvia muutoksia geenien toiminnassa.

\section{Aineisto ja menetelmät}

Ruokintakokeen eläimet ja koejärjestely on kuvattu Elon ym. (2012) tutkimuksessa. Geenitoiminnan tutkimista varten lehmiltä kerättiin biopsioimalla näytteet ihonalaisesta rasvasta 8 päivää ennen poikimista, yksi päivä poikimisen jälkeen ja 9 päivää poikimisen jälkeen. Rasvanäyte jäädytettiin näytteenottohetkellä välittömästi nestetypen avulla ja säilytettiin sen jälkeen $-80^{\circ} \mathrm{C}$ :ssa pakastimessa.

Kudosnäytteistä eristettiin kokonais-RNA 18 ihonalaisesta rasvakudosnäytepalasta RNeasy Lipid Tissue Mini kit:n (Qiagen GmbH, Hilden Saksa) menetelmän mukaisesti. Leikatut näytepalat homo- 
genisoitiin, kokonais-RNA:n määrä kvantitoitiin ja kokonais-RNA:n laatu arvioitiin Elon ym. (2012) tutkimuksessa esitetyillä tavoilla. Lähetti-RNA:sta syntetisoitiin cDNA:ta Rochen Transcriptor First Strand cDNA Synthesis Kit:n avulla (Roche Diagnostics GmbH, Mannheim, Saksa). cDNA:n synteesi tehtiin kahdeksan $200 \mu$ l:n putken stripeillä. RNA-alukeseos valmistettiin kokonais-RNA:sta, oligo(dT)- ja heksameeri-alukkeista. Kvantitatiivinen PCR pipetoitiin 384 -levylle Eppendorfin epMotion 5075 -pipetointirobotilla (Eppendorf AG, Hampuri, Saksa). PCR:n reaktiotilavuus oli $10 \mu \mathrm{l}$ ja käytetty alukekonsentraatio oli 2,5 $\mu \mathrm{M}$. Kvantitatiiviset PCR:t tehtiin Rochen Light Cycler 480 laitteella Helsingin yliopiston DNA-sekvensoinnin ja genomiikan laboratoriossa.

Alukeparit suunniteltiin Primer3 -ohjelman (Rozen \& Skaletsky 2000) avulla seuraaville geeneille: adiponektiini $(A D I P O Q)$, eukaryoottien translaation aloitustekijä 3, alayksikkö K (EIF3K), interleukiini-6 (IL-O), insuliinireseptorisubstraatti (IRS), leptiini $(L E P)$, fosfoenolipyruvaattikarboksikinaasi $1(P C K 1)$, peroksisomiproliferaattoreilla aktivoituva reseptori gamma $(P P A R \gamma)$, retinolia sitova proteiini $4(R B P 4)$, resistiini $(R E S)$, tuumorinekroositekijä-alfa $(T N F \alpha)$. Näistä sisäisenä kontrollina käytettiin $E I F 3 K$-geeniä.

Kvantitatiivisesta PCR:stä saatu aineisto analysoitiin käyttäen 2- $\Delta \Delta C T$ menetelmää (Livak ja Schmittgen 2001). Geenitoiminnan analysoinnissa käytettiin ei-parametrisiä testejä, sillä aineisto ei kaikkien geenien osalta ollut normaalijakautunut. Kruskal-Wallisin testillä analysointiin ryhmien välisiä eroja. Geenitoiminnan muutokset analysoitiin käyttäen R -tilastopaketin ohjelmia (http://www.rproject.org/). Lisäksi poikimisen jälkeen (1 ja 9 päivää) kandidaattigeenien toiminnassa tapahtuneita muutoksia analysoitiin merkkitestillä insuliiniresistenssin näkökulmasta. Tätä varten kirjallisuudesta kerättiin tietoja tutkittujen geenien toiminnan muutoksista ja näistä tiedoista muodostettiin hypoteesit kullekin geenille sen toiminnan muutoksen suunnasta. Merkkitestillä analysoitiin, monellako eläimellä geenitoiminta oli muuttunut hypoteesin mukaiseen suuntaan.

\section{Tulokset ja niiden tarkastelu}

Yhdistämällä koe- ja kontrollinäytteet yhdeksi aineistoksi lehmien rasvakudoksen geenitoiminnasta löytyi eroja $(\mathrm{P}<0,05)$ kolmen näytteenottohetken välillä seuraavilla geeneillä: $A D I P O Q, L E P, R E S$, $P P A R \gamma$ ja $R B P 4$ (Taulukko 1). Erityisesti leptiinigeenin toiminnan väheneminen poikimisen jälkeen näkyy suurimpana tilastollisena merkitsevyytenä $(\mathrm{P}<0,001)$. Leptiinigeenin toiminta väheni poikimisen jälkeen, 1 ja 9 päivää poikimisen jälkeen se oli keskimäärin $46 \%$ toiminnan määrästä 8 päivää ennen poikimista.

Taulukko 1. Geenitoiminnassa havaittavat erot kolmen näytteenottoajankohdan välillä. Testauksessa on käytetty Kruskall-Wallisin järjestyssummatestiä.

\begin{tabular}{lll}
\hline Geeni & Riskitaso $(\mathrm{P})$ & Testisuure $\left(\chi^{2}\right)$ \\
\hline ADIPOQ & $0,021^{*}$ & 7,681 \\
IL6 & 0,876 & 0,265 \\
LEP & $0,001 * * *$ & 13,510 \\
RES & $0,026^{*}$ & 7,308 \\
TNF $\alpha$ & 0,678 & 0,777 \\
IRS1 & 0,118 & 4,281 \\
PPAR $\gamma$ & $0,018^{*}$ & 8,000 \\
RBP4 & $0,041^{*}$ & 6,397 \\
PCK1 & 0,011 & 8,998 \\
\hline$* * *(\mathrm{P}<0,001), * *(\mathrm{P}<0,01), *(\mathrm{P}<0,05)$ ja o $(\mathrm{P}<0,10)$
\end{tabular}

Sadri ym. (2010) tutkivat osittain samojen geenien toiminnan muutoksia rasvakudoksessa 8 viikkoa ennen, 1 päivä ja 5 viikkoa jälkeen poikimisen. He eivät havainneet muutoksia $I R S: n$ toiminnassa mutta $T N F \alpha$ :n toiminta lisääntyi tilastollisesti merkitsevästi $(\mathrm{P}=0,006)$ poikimisen jälkeen (Sadri ym. 2010). Lemor ym. (2009) eivät löytäneet $A D I P O Q: n$ ja $L E P: n$ toiminnassa muutoksia verratessaan viikkoa ennen ja 3 viikkoa jälkeen poikimisen otettuja näytteitä. Sen sijaan Sumner-Thomson ym. (2011) tutkimuksessa $L E P: n$ toiminta väheni tilastollisesti merkitsevästi $(\mathrm{P}=0,004)$ verrattaessa 30 päivää ennen ja 14 päivää poikimisen jälkeen otettuja näytteitä.

Koe- ja kontrolliryhmien välisiä geenitoiminnan eroja analysoitiin kolmena näytteenottoajankohtana käyttäen Kruskall-Wallisin järjestyssummatestiä. Ainoastaan ennen poikimista otetuissa näytteis- 
sä oli ryhmien välisiä eroja, tilastollisesti merkitsevin ero oli insuliinireseptorisubstraattigeenin toiminnassa $(\mathrm{P}=0,021)$. Lisäksi suuntaa antavasti eroja oli adiponektiini- ja resistiinigeenien toiminnassa (Taulukko 2). Kaikkien kolmen geenin toiminta oli suurempaa rajoitetusti ruokittujen ryhmässä kuin vapaasti ruokittujen ryhmässä.

Taulukko 2. Kontrolli- ja koeryhmien välinen ero geenitoiminnassa eri näytteenottoajankohtina. Testauksessa on käytetty Kruskall-Wallisin järjestyssummatestiä.Ylempi luku on riskitaso (P) ja alempi luku on testisuure $\left(\chi^{2}\right)$.

\begin{tabular}{llcc}
\hline Geeni & -8 päivää & +1 päivä & +9 päivää \\
\hline ADIPOQ & 0,059 o & 0,294 & 0,749 \\
& 3,574 & 1,103 & 0,102 \\
IL6 & 0,248 & 0,834 & 0,142 \\
& 1,335 & 0,044 & 2,159 \\
LEP & 0,294 & 0,142 & 0,749 \\
& 1,103 & 2,162 & 0,102 \\
RES & 0,074 o & 0,834 & 0,225 \\
& 3,188 & 0,044 & 1,474 \\
TNF $\alpha$ & 0,916 & 0,834 & 0,406 \\
& 0,011 & 0,044 & 0,690 \\
IRS1 & $0,021 *$ & 0,834 & 0,225 \\
& 5,338 & 0,044 & 1,474 \\
PPAR $\gamma$ & 0,916 & 0,401 & 0,338 \\
RBP4 & 0,011 & 0,706 & 0,918 \\
& 0,345 & 0,916 & 0,142 \\
PCK1 & 0,893 & 0,011 & 2,159 \\
& 0,338 & 0,834 & 0,655 \\
\hline
\end{tabular}

***(P<0,001), **(P<0,01), $*(\mathrm{P}<0,05)$ ja o $(\mathrm{P}<0,10)$

Merkkitestillä analysoitiin yksilöittäin poikimisen jälkeen (1 ja 9 päivää) geenitoiminnassa tapahtuneita muutoksia insuliiniresistenssin näkökulmasta. Tällöin geenitoiminnan perusteella kolmella vapaasti ruokitulla lehmällä on suuntaa antavasti $(\mathrm{P}<0,10)$ ja yhdellä rajoitetusti ruokitulla lehmällä on tilastollisesti merkitsevästi $(\mathrm{P}<0,05)$ insuliiniresistenssin piirteitä.

\section{Johtopäätökset}

Ruokinnan rajoittaminen vaikutti insuliinireseptorisubstraattigeenin toimintaan $(\mathrm{P}=0,021)$. Lisäksi rajoitetusti ja vapaasti ruokittujen ryhmien välillä oli suuntaa antavasti eroja adiponektiinigeenin $(\mathrm{P}=0,059)$ ja resistiinigeenin $(\mathrm{P}=0,074)$ toiminnassa. Selkein ajallinen geenitoiminnan ero havaittiin leptiinigeenissä $(\mathrm{P}=0,001)$, jonka toiminta väheni alle puoleen poikimisen jälkeen. Peroksisomiproliferaattoreilla aktivoituva reseptori gamma-, retinolia sitova proteiini 4- ja resistiinigeenien toiminnassa havaittiin ajallinen geenitoiminnan ero riskitasolla $\mathrm{P}<0,05$.

\section{Kirjallisuus}

Bossaert, P., Leroy, J.L.M.R., De Vliegher, S. \& Opsomer, G. 2008. Interrelations between glucose-induced insulin response, metabolic indicators, and time of first ovulation in high-yielding dairy cows. Journal of Dairy Science 91: 3363-3371.

Elo, K., Gulzar, Z., Hoti, F., Jaakkola, S., Salin, S., Sillanpää, M., Taponen, J., Vanhatalo, A. \& Kokkonen, T. 2012. Ummessaoloajan ruokintatason vaikutus lypsylehmien maksan geenitoimintaan. Teoksessa Maataloustieteen päivät 10.-11.1.2012. Suomen Maataloustieteellisen Seuran julkaisuja. Saatavilla Internetissä: http://www.smts.fi. 
Kokkonen, T., Taponen, J., Anttila, T., Syrjälä-Qvist, L., Delavaud, C., Chilliard, Y., Tuori, M. \& Tesfa, A.T. 2005. Effect of body fatness and glucogenic supplement on lipid and protein mobilization and plasma leptin in dairy cows. Journal of Dairy Science 88: 1127-1141.

Lemor, A., Hosseini, A., Sauerwein, H. \& Mielenz, M. 2009. Transition period-related changes in the abundance of the mRNAs of adiponectin and its receptors, of visfatin, and of fatty acid binding receptors in adipose tissue of high-yielding dairy cows. Domestic Animal Endocrinology 37: 37-44.

Livak, K.J. \& Schmittgen, T.D. 2001. Analysis of relative gene expression data using real-time quantitative PCR and the 2- $\triangle \Delta C T$ method. Methods 25: 402-408.

Millward, C.A., DeSantis, D., Hsieh, C-H., Heaney, J.D., Pisano, S., Olswang, Y., Reshef, L., Beidelschies, M., Puchowicz, M. \& Croniger, C.M. 2010. Phosphoenolpyruvate carboxykinase (Pck1) helps regulate the triglyceride/fatty acid cycle and development of insulin resistance in mice. The Journal of Lipid Research 51: 1452-1463.

Mukesh, M., Bionaz, M., Graugnard, D.E., Drackley, J.K. \& Loor, J.J. 2009. Adipose tissue depots of Holstein cows are immune responsive: Inflammatory gene expression in vitro. Domestic Animal Endocrinology 38 : $168-178$.

Nielsen, A. Hameleers, A., Young, F.J., Larsen, T. \& Friggens, N.C. 2010. Energy intake in late gestation affects blood metabolites in early lactation independently of milk production in dairy cows. Animal 4: 52-60.

Pires, A.A.J., Souza, A.H. \& Grummer, R.R. 2007. Induction of hyperlipidemia by intravenous infusion of tallow emulsion causes insulin resistance in holstein cows. Journal of Dairy Science 90: 2735-2744.

Pittas, A.G., Nandini, J.A. \& Greenberg, A.S. 2004. Adipocytokines and insulin resistance. The Journal of Clinical Endocrinology \& Metabolism 89: 447-452.

Rozen, S. \& Skaletsky, H.J. 2000. Primer3 on the WWW for general users and for biologist programmers. In: Krawetz, S. \& Misener, S. (toim.) Bioinformatics Methods and Protocols: Methods in Molecular Biology. Humana Press, Totowa, NJ, ss. 365-386.

Sadri, H., Bruckmaier, R. M., Rahmani, H. R. Ghorbani, G. R. Morel, I. \& van Dorland, H. A. 2010. Gene expression of tumour necrosis factor and insulin signalling-related factors in subcutaneous adipose tissue during the dry period and in early lactation in dairy cows. Journal of Animal Physiology and Animal Nutrition 94: 194202.

Sadri, H., Mielenz, M., Morel, I., Bruckmaier, R.M. \& van Dorland, H.A. 2011. Plasma leptin and mRNA expression of lipogenesis and lipolysis-related factors in bovine adipose tissue around parturition. Journal of Animal Physiology and Animal Nutrition 95: 790-797.

Salin, S., Kokkonen, T., Kuitunen, M., Taponen, J., Elo, K. \& Vanhatalo, A. 2010. Juoksutusmahaan infusoidun rasvalisän vaikutus ummessaolevien lehmien insuliiniresistenssin kehittymiseen. Julkaisussa: Maataloustieteen Päivät 12.-13.1.2010. Suomen Maataloustieteellisen Seuran julkaisuja no 26. Toim. Anneli Hopponen.Viitattu 29.11.2011. Julkaistu 11.1.2010. Saatavilla Internetissä: http://www.smts.fi.

Sumner, J.M. \& McNamara, J.P. 2007. Expression of lipolytic genes in the adipose tissue of pregnant and lactating holstein dairy cattle. Journal of Dairy Science 90: 5237-5246.

Sumner-Thomson, J.M., Vierck, J.L. \& McNamara, J.P. 2011. Differential expression of genes in adipose tissue of first-lactation dairy cattle. Journal of Dairy Science 94: 361--369.

Yang, Q., Graham, T.E., Mody, N., Preitner, F., Peroni, O.D., Zabolotny, J.M., Kotani, K., Quadro, L. \& Kahn, B.B. 2005. Serum retinol binding protein 4 contributes to insulin resistance in obesity and type 2 diabetes. Nature 436: 356-362. 